\title{
Spatiotemporal analysis of rabies in cattle in central Mexico
}

\author{
Isabel Bárcenas-Reyes, ${ }^{1}$ Diana Paulina Nieves-Martínez, ${ }^{1}$ José Quintín Cuador-Gil, ${ }^{2}$ \\ Elizabeth Loza-Rubio, ${ }^{3}$ Sara González-Ruiz, ${ }^{1}$ Germinal Jorge Cantó-Alarcón, ${ }^{1}$ \\ Feliciano Milián-Suazo ${ }^{1}$
}

${ }^{1}$ Faculty of Natural Sciences, Autonomous University of Querétaro, Querétaro, Mexico; ${ }^{2}$ Department of

Physics, "Hermanos Saíz Montes de Oca” University of Pinar del Río, Pinar del Río, Cuba; ${ }^{3}$ National

Center for Disciplinary Research in Microbiology, National Institute of Forestry, Agricultural and Livestock

Research (CENID-MICROBIOLOGY-INIFAP), Mexico City, Mexico

\begin{abstract}
Spatial epidemiology of bat-transmitted rabies in cattle has been limited to spatial distribution of cases, an approach that does not identify hidden patterns and the spread resulting in outbreaks in endemic and susceptible areas. Therefore, the purpose of this study was to determine the relationship between the three variables average annual maximum, annual minimum temperature and precipitation in the region on the one hand, and the spatial distribution of cases on the other, using geographic information systems and co-Kriging considering that these environmental variables condition the existence of the rabies vector Desmodus rotundus. A stationary behaviour between the primary and the secondary variables was verified by basic statistics and moving window statistics. The directions of greater and lesser spatial continuity were determined by experimental cross-semivariograms. It was found that the highest risk for bovine paralytic rabies occurs
\end{abstract}

Correspondence: Feliciano Milián-Suazo, Faculty of Natural Sciences, Autonomous University of Querétaro, Av. de las Ciencias S/N Juriquilla, Delegación Santa Rosa Jáuregui, C. P. 76230, Querétaro, Mexico.

Tel. 01.44221921200 (ext. 5384).

E-mail: feliciano.milian@uaq.mx

Key words: Rabies; Desmodus rotundus; Epidemiology; Cattle; Mexico.

Conflict of interest: the authors declare no potential conflict of interest.

Funding: Researh Support Funding - UAQ, project number FNV201408, and Natural Sciences Faculty.

Received for publication: 25 July 2019.

Revision received: 27 September 2019.

Accepted for publication: 5 October 2019.

${ }^{\circ}$ Copyright: the Author(s), 2019

Licensee PAGEPress, Italy

Geospatial Health 2019; 14:805

doi:10.4081/gh.2019.805

This article is distributed under the terms of the Creative Commons Attribution Noncommercial License (CC BY-NC 4.0) which permits any noncommercial use, distribution, and reproduction in any medium, provided the original author(s) and source are credited. in areas known as La Huasteca Potosina and La Sierra Gorda that are characterized by a maximum temperature of $29.5^{\circ} \mathrm{C}$, a minimum temperature of $16.5^{\circ} \mathrm{C}$ and precipitation of $1200 \mathrm{~mm}$. A risk estimation map was obtained for the presence of rabies with a determination coefficient greater than $95 \%$, and a correlation coefficient greater than 0.95 . Our conclusion is that ordinary coKriging provides a better estimation of risk and spatial distribution of rabies than simple Kriging, making this the method recommended for risk estimation and regional distribution of rabies.

\section{Introduction}

Rabies is a lethal zoonotic disease caused by a neurotropic virus of the genus Lyssavirus, which affects all types of warmblooded animal species around the world. In humans, rabies is responsible for about 60,000 deaths worldwide each year (WHO, 2013; Hampson et al., 2015). In cattle and other animal species, it is estimated that the number of cases per year is more than 50,000 (Loza-Rubio et al., 2012; PAHO, 2013; Vigilato et al., 2013). Currently, in Latin America and the Caribbean, the risk for rabies in humans and cattle is due to the bite of the blood-sucking bat Desmodus rotundus. In Mexico, between 2007 and 2015 the number of cases reported was 1,872 , in different livestock species in 25 endemic states; the cattle industry loses more than United States dollars 2.6 million a year because of rabies. The number of human cases transmitted by wildlife for the years 2000 to 2006 was 23, 14 of which related to vampire bites (Zarza et al., 2017).

The progressive alteration of the bat's habitat has favoured the spread of rabies over the years, and cases have appeared in areas previously free of the disease. Different studies have reported that $D$. rotundus has increased its range of distribution to areas higher than 1,500 meters above the mean sea level, and that climatic variables such as temperature and precipitation influence the movement of bats within the same geographic area. This phenomenon allows the bats to maintain an exchange of shelters near the food source, which favours infection between bats and transmission of rabies to livestock (Gomes et al., 2010; Aguirre et al., 2012; de Andrade et al., 2016; de Thoisy et al., 2016). Due to continuous human invasion of areas occupied by vampire bats, the number of cases in livestock and people is increasing. There is solid evidence that the vampire bat population's distribution has expanded because of climate change, with higher temperatures increasing the risk of disease spread to new regions (Johnson et al., 2014).

Geographical Information Systems, remote sensing, spatial statistics and spatially explicit mathematical models are tools use- 
ful for the study, prevention and control of rabies (Clements and Pfeiffer, 2009; Mengistu and Haile, 2017). Geostatistics can estimate and predict the distribution of rabies in cattle successfully, even in spatial surveillance data with respect to the potential occurrence in non-sampled environments (Escobar, 2016; Bonwitt et al., 2018), especially when sampling is biased due to attributes of place (Guo et al., 2013; de Andrade et al., 2016). Using these methods in the Amazonian region of Brazil, high-risk areas for rabies in humans and cattle were identified in extensive deforested areas with large herds of cattle and roads (de Andrade et al., 2016). Recently, in Colombia, high-risk areas were determined in various types of ecosystems suggesting that an infectious disease can remain over time even if the ecological variables are not perfectly suited (Cárdenas-Contreras, 2017). Spatial studies have also been useful for supporting practices of rabies control, especially for vaccination of cattle against new outbreaks or modelling various scenarios, including different levels of climate variables, time and the geographical ranges of humans, foxes, bats and dogs (WHO, 2013).

While the number and quality of epidemiological spatial applications of rabies are increasing, the full potential of these methods has not yet been achieved (Rodenbusch et al., 2016). The main critical control point observed in spatial distribution of rabies in cattle is that municipalities that send high numbers of biological material for analysis to the laboratory are those that also present the highest number of cases (Hayes and Piaggio, 2018), i.e. the number of cases is not representative of the population of cases in a region.

The proximity to areas with high incidence of rabies with climatic variables that favour the presence of bats is of special interest for an understanding of the presence and spread of the disease in new geographic regions. It has been reported that precipitation and temperature are factors that determine the distribution of the vector and, therefore, the distribution of the disease (BárcenasReyes et al., 2015). Therefore, the objective of this study was to predict the spatial risk and the space distribution of cases of rabies in livestock explained by the climatic variables, such as maximum and minimum average annual temperature and average annual precipitation (AP), in central Mexico with the use of multivariate geostatistical methods.

\section{Materials and Methods}

Information of cases was collected between 2001 and 2014 in the States Guanajuato, Queretaro and San Luis Potosi in central Mexico. Presence of the viral N protein in the direct immunofluorescence laboratory test of brain tissue was used as case definition. Coordinates for about $70 \%$ of the cases were available, while coordinates for the remaining cases were obtained either from the Mexico's National Institute of Statistics, Geography and Informatics (INEGI)'s database or applying Google Earth for those not recorded in the INEGI's data base using the closest locality as the point of reference. In addition to coordinates, species, month and year of case presentation were also available.

Rapid Extractor of Climatological Information III (ERIC III) (IMTA, 2006) was used to generate a database of the environmental variables maximum annual average temperature $\left(\mathrm{T}_{\max }\right)$, minimum annual average temperature $\left(\mathrm{T}_{\text {min }}\right)$ and the AP for the three states. A bivariate correlation between the number of cases and the climatic variables by municipality was performed with the statistical package SPSS 22.0, released in 2013 (SPSS IBM Corp., Armonk, NY). Statistical significance was set at the $\mathrm{P}=0.05$ level. The following steps were performed for each variable: i) exploratory analysis to obtain a model that better represents the characteristics of variability and the spatial correlation of the phenomenon under study; ii) spatial tendency using series of locations in the simulated study area; and iii) estimation of the variables with validation of the models (Barrios-Gómez et al., 2019).

Assuming spatial continuity, co-Kriging was applied on observed cases of rabies in cattle to obtain values for each location. The number of cases was aggregated by municipality, for a smoothing process and to reduce the random error. To establish the spatial relationship between the values of $\mathrm{T}_{\max }, \mathrm{T}_{\min }$ and AP values throughout the estimation domain with the number of cases, we used ordinary Kriging from the geostatistical analyst extension of ArcMap v. 10 (ESRI, Redlands, CA, USA). Kriging and coKriging are linear-weighted interpolation methods, whose weights not only depend on distance, but also on the direction and orientation of the neighbouring data to unsampled locations. Co-Kriging is an extension of ordinary Kriging in which observed covariates are used to improve the precision of the interpolation of the variable of interest.

Table 1. The analytics expression of cross-variograms obtained to use in co-Kriging methods.

\begin{tabular}{|c|c|c|c|c|c|c|}
\hline Semivariogram & Variable combination & Nugget & Sill & Model & Major range & Minor range \\
\hline$\gamma_{11}$ & $\mathrm{NC} \_\mathrm{NC}$ & 244.82 & 396.3 & Spherical & 0.91 & 0.90 \\
\hline$\gamma_{12}$ & NC_T $T_{\text {max }}$ & 0.0 & 4.30 & Spherical & 0.91 & 0.90 \\
\hline$\gamma_{13}$ & $\mathrm{NC}_{-} \mathrm{T}_{\text {min }}$ & 0.0 & 2.67 & Spherical & 0.91 & 0.90 \\
\hline$\gamma_{14}$ & NC_AP & 0.0 & 8544.2 & Spherical & 0.91 & 0.90 \\
\hline$\gamma_{22}$ & $\mathrm{~T}_{\max \_} \mathrm{T}_{\max }$ & 0.0 & 0.82 & Spherical & 0.91 & 0.90 \\
\hline$\gamma_{23}$ & $\mathrm{~T}_{\max } \mathrm{T}_{\min }$ & 0.0 & 0.10 & Spherical & 0.91 & 0.90 \\
\hline$\gamma_{24}$ & $\mathrm{~T}_{\max \_} \mathrm{AP}$ & 0.0 & 6.77 & Spherical & 0.91 & 0.90 \\
\hline$\gamma_{33}$ & $\mathrm{~T}_{\min \_} \mathrm{T}_{\min }$ & 0.05 & 0.94 & Spherical & 0.91 & 0.90 \\
\hline$\gamma_{34}$ & $\mathrm{~T}_{\text {min__ }} \mathrm{AP}$ & 0.0 & 20.44 & Spherical & 0.91 & 0.90 \\
\hline$\gamma_{44}$ & $\mathrm{AP}_{-} \mathrm{T}_{\text {min }}$ & 0.0 & 221400.0 & Spherical & 0.91 & 0.90 \\
\hline
\end{tabular}

A summary of the models made with co-Kriging and the defining parameters. The linear model of coregionalization was verified with the nugget and the sill values (Caro-Benito, 2012; Wackernagel, 1998). NC, number of cases; $\mathrm{T}_{\max }$, maximum annual average temperature; $\mathrm{Tmin}$, minimum annual average temperature; $\mathrm{AP}$, average precipitation. 
First, the relationship between the climatic variables with the number of cases was analysed considering that those variables condition the existence of cases. The idea was to estimate the number of cases as the primary variable and use climatic variables as the secondary or auxiliary variables. To adjust the parameters, variance and covariance, a linear coregionalization model was used (Caro-Benito, 2012). This model establishes that the individual semivariograms and the crusader are linear combinations of semivariogram models. This approach allows the explanation of a variable based on other auxiliary variables spatially correlated using a cross-semivariogram (Table 1).

The analytic expression of the cross-semivariogram used was (Eq. 1):

$\gamma(\mathrm{h})=\mathrm{EP}+\mathrm{S}_{\mathrm{I}} \mathrm{ll}_{1} \operatorname{Mod}_{1}\left(\alpha_{\mathrm{x} 1} \alpha_{\mathrm{y} 2}\right)+\mathrm{S}_{\mathrm{I}} \mathrm{ll}_{2} \operatorname{Mod}_{2}\left(\alpha_{\mathrm{x} 1} \alpha_{\mathrm{y} 2}\right)+\mathrm{S}_{\mathrm{I}} \mathrm{II}_{3} \operatorname{Mod}_{3}$ $\left(\alpha_{\mathrm{x} 1} \alpha_{\mathrm{y} 2}\right)+\mathrm{S}_{\mathrm{I}} \mathrm{II}_{4} \operatorname{Mod}_{4}\left(\alpha_{\mathrm{x} 1} \alpha_{\mathrm{y} 2}\right)$

where $h$ is the distance that separates a number of data pairs, EP the expression of the sum of the basic spherical models for the four variables, Sill Mod the area of the curve where the values no longer correlate to each model and $\alpha$ the range of scope of the variance, i.e. the distance from which the samples begin to be independent of each other.

The relationship between the number of cases with the three climatic variables and combinations of those with cases was calculated to evaluate the effectivity of the methods. Direct and cross validation, which shows the continuity data behaviour of the direction $45^{\circ}$, was also performed. The analytic expression of the spatial variability was (Eq. 2):

$(\mathrm{G} / \mathrm{h})=\mathrm{Co}+\mathrm{C}_{1}+\operatorname{Mod}_{1}\left(\alpha_{\mathrm{x} 1} \alpha_{\mathrm{y} 1}\right)+\mathrm{C}_{2}+\operatorname{Mod}_{2}\left(\alpha_{\mathrm{x} 2} \alpha_{\mathrm{y} 2}\right)+\mathrm{C}_{3}+$ $\operatorname{Mod}_{3}\left(\alpha_{\mathrm{x} 3} \alpha_{\mathrm{y} 3}\right)$

Eq. 2

where $\mathrm{G} / \mathrm{h}$ is the number of data pairs that are at a distance, $\alpha$ the range of scope of the variance, Co the nugget effect and $\mathrm{C}_{1}, \mathrm{C}_{2}, \mathrm{C}_{3}$ the structural components of the variance corresponding to the variability explained by the model (Mod). The linear model of coregionalization was verified with the nugget value, which measures the nugget effect, and the sill value, which measures the plateau, both values unique for each model (Wackernagel, 1998).

\section{Results}

Table 2 shows the number of cases per year, the number of municipalities affected, the annual average maximum, the minimum temperature and the average AP for the years 2001 to 2013. It can be observed that the number of municipalities affected increases with the maximum temperature varied between $29.0^{\circ} \mathrm{C}$ and $29.5^{\circ} \mathrm{C}$, the minimum temperature between $16.0^{\circ} \mathrm{C}$ and 16.5 ${ }^{\circ} \mathrm{C}$, and the precipitation between 1,190 and 1,200 mm (Tables 3 and 4).

Figure 1 shows the risk estimation map for the presence of cases based on the three climatic variables and the number of cases. It can be observed that the region known as La Huasteca Potosina, is the region with the highest number of cases and the area with the highest risk for more cases. Figure 2 shows the estimated risk obtained with co-Kriging for the presence of cases based on the three climatic variables and the number of cases reported. It can be observed that the region with the highest risk for the presence of cases in cattle is La Huasteca Potosina, in the

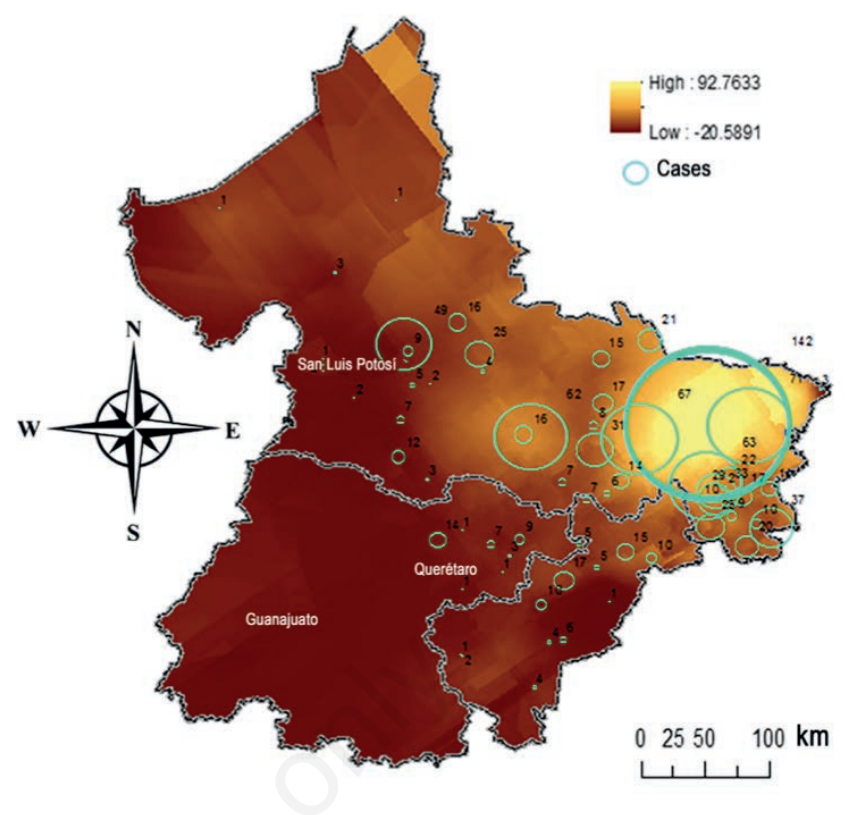

Figure 1. Spatial distribution of risk for the presence of cases of rabies in the study area. Light colour shades indicate a higher number of cases. The radii of the green circles represent the number of cases reported in the different municipalities (larger circles - more cases). Numbers in black are the real number of cases by municipality for the study period. The figure is based on $T_{\max }$, $T_{\min }$ and annual precipitation by co-Kriging. Higher quadratic mean error means higher risk for cases. Green circles indicate number of cases by municipality.

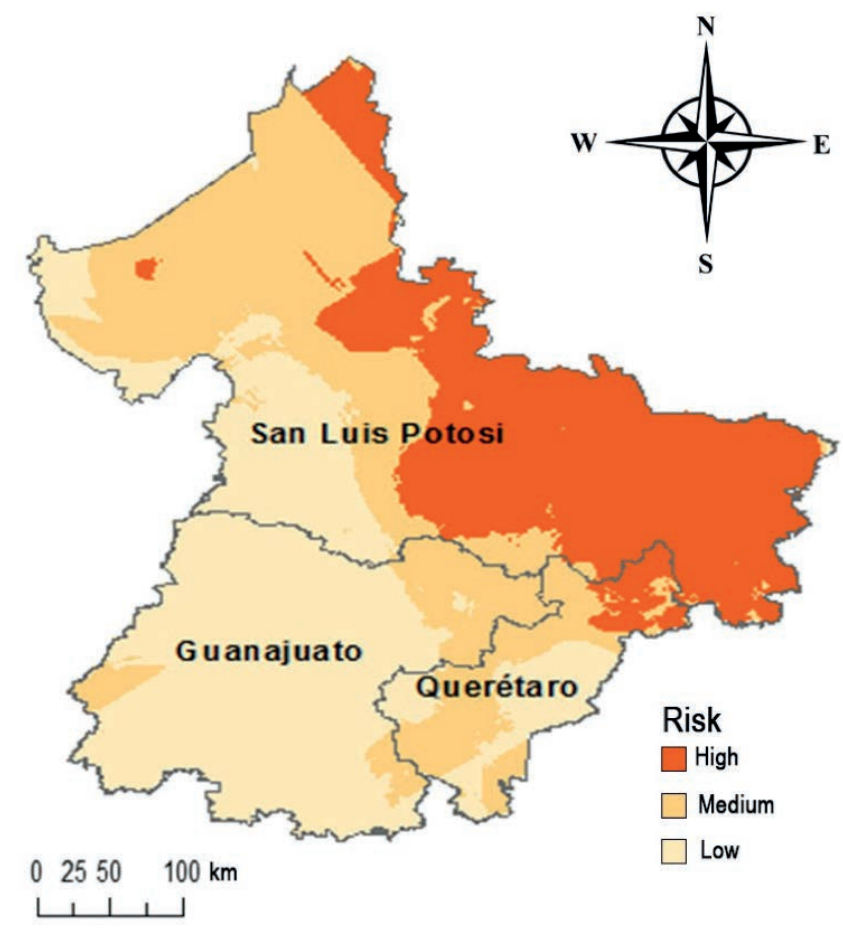

Figure 2. Risk distribution of cases of rabies in the study area. The figure is based on $T_{\max }, T_{\min }$ and annual precipitation by coKriging. 
Northeast of the State of San Luis Potosí, and the region known as La Sierra Gorda in the Northeast of the State of Queretaro. There are regions of low risk in other parts of the study area, where, based on the climatic variables considered, the presence of cases is only probable. In fact, a low number of cases has recently been reported.

In the variogram, the presence of anisotropy was identified, which was also checked with the calculation of the omnidirectional and the directional semivariograms, where $45^{\circ}$ was the direction of higher and lower spatial continuity. To validate the estimation between the prediction using a multivariate analysis and the univariate analysis explaining the area of risk, individual cross validations were built. The middle quadratic error measures the amount of error existing between two datasets, usually observed and predicted datasets. This value was obtained by multivariate analysis comparing the robustness of the Kriging and co-Kriging methods; 0.98 for Kriging and 1.4 for co-Kriging, respectively (data not shown).

Table 2. Number of cases of rabies in cattle by year, municipality and climatic variables in central Mexico, 2001-2013.

\begin{tabular}{lccccc} 
Year & Number of cases & Affected municipalities & $\begin{array}{c}\text { Average } \\
\mathrm{T}_{\max }\left({ }^{\circ} \mathrm{C}\right)\end{array}$ & $\begin{array}{c}\text { Average } \\
\mathrm{T}_{\min }\left({ }^{\circ} \mathrm{C}\right)\end{array}$ & $\begin{array}{c}\text { Average } \\
\text { AP }(\mathrm{mm})\end{array}$ \\
2001 & 10 & 6 & 30.82 & 17.97 & $1,470.8$ \\
2002 & 98 & 16 & 29.28 & 16.34 & $1,196.0$ \\
\hline 2003 & 121 & 13 & 29.33 & 16.53 & $1,222.1$ \\
2004 & 93 & 11 & 29.31 & 16.40 & $1,228.8$ \\
\hline 2005 & 88 & 18 & 29.32 & 16.46 & $1,213.3$ \\
2006 & 52 & 12 & 29.29 & 1.27 & $1,216.7$ \\
\hline 2007 & 56 & 17 & 29.50 & 16.43 & $1,216.8$ \\
2008 & 78 & 22 & 29.32 & 16.50 & $1,217.2$ \\
\hline 2009 & 87 & 22 & 29.33 & 16.39 & $1,225.7$ \\
2010 & 90 & 22 & 29.34 & 29.3 & $1,210.1$ \\
2011 & 136 & 25 & 29.32 & 16.41 & $1,213.5$ \\
\hline 2012 & 68 & 26 & 29.31 & $1,197.8$ \\
\hline
\end{tabular}

$\mathrm{T}_{\max }$, maximum annual average temperature; $\mathrm{T}_{\min }$, minimum annual average temperature; $\mathrm{AP}$, annual precipitation.

Table 3. Spatial characteristics and areas with presence of cases of rabies in central Mexico over the period 2001-2007.

\begin{tabular}{|c|c|c|}
\hline Year & Pattern & Places with cases of rabies \\
\hline 2001 & $\begin{array}{l}\text { Small number of cases reported from the SLP State } \\
\text { in regions with average temperature of } 24.4^{\circ} \mathrm{C} \text { and } \\
\text { average precipitation of } 1,470.8 \mathrm{~mm} .\end{array}$ & $\begin{array}{l}\text { Aquismón, Lagunilla, Sta. Catarina. Tamasopo, Tancanhuitz, Tampamolón, } \\
\text { and San Martín in the State of SLP. }\end{array}$ \\
\hline 2002 & $\begin{array}{l}\text { Rabies spreads to free areas and the number of cases } \\
\text { increases. Cases presented at average temperature of } \\
22.8^{\circ} \mathrm{C} \text { and average precipitation of } 1,195.97 \mathrm{~mm} \text {. }\end{array}$ & $\begin{array}{l}\text { Aquismón, Axtla, Ciudad Valles, Coxcatlan, Ebano, Rayón, San Vicente, Sta. } \\
\text { Catarina, Tampacán, Tamazunchale, Tancanhuitz, Tampamolón, Tanlajás, } \\
\text { Tanquian and San Martín in the State of SLP. }\end{array}$ \\
\hline 2003 & $\begin{array}{l}\text { Rabies spreads to most of SLP State and arises } \\
\text { in new places. }\end{array}$ & $\begin{array}{l}\text { Alaquines, Aquismón, Armadillo, Axtla, Ciudad Valles, Rio verde, San Vicente, } \\
\text { Tampacán, Tamazunchale, Tancanhuitz, Tampamolónn, Tanlajás, and Venado in the } \\
\text { State of SLP. }\end{array}$ \\
\hline 2004 & $\begin{array}{l}\text { The number of cases reported decreases at average } \\
\text { temperature of } 22.9^{\circ} \mathrm{C} \text { and precipitation of } 1,228.7 \mathrm{~mm} \text {. }\end{array}$ & $\begin{array}{l}\text { Aquismón, Axtla, Ciudad Valles, Coxcatlán, Ebano, El Naranjo. } \\
\text { Huehuetla, San Vicente, Sta. Catarina, Tamuín, Tanlajás, and Xilitla in the State of SLP. }\end{array}$ \\
\hline 2005 & $\begin{array}{l}\text { The number of cases reported decreases; however, } \\
\text { the disease spreads to more places in SLP, for the first time } \\
\text { also reported in QRO State. }\end{array}$ & $\begin{array}{l}\text { Alaquines, Aquismón, Armadillo, Axtla, Ciudad Valles, Coxcatlán, Lagunilla, Rayón, } \\
\text { San Luis, Río verde, Sta. Catarina, San Martín, Tamuín, Tamasopo, Xilitla belonging } \\
\text { to the state of SLP and towns of Jalpan, and Landa de Matamoros in the State of QRO. }\end{array}$ \\
\hline 2006 & $\begin{array}{l}\text { Cases are reported in places with average temperature } \\
\text { of } 22.8^{\circ} \mathrm{C} \text { and average precipitation of } 1,216.7 \mathrm{~mm} .\end{array}$ & $\begin{array}{l}\text { Ciudad del Maíz, Ciudad Valles, Coxcatlán, Lagunilla, Río Verde, Sta. Catarina, } \\
\text { Sto. Domingo, Tamasopo, Tamuín, Tancanhuitz, Tierra Nueva in the state of SLP, } \\
\text { and Landa de Matamoros in the State of QRO. }\end{array}$ \\
\hline 2007 & $\begin{array}{l}\text { Places with high prevalence in SLP State include } \\
\text { Ciudad Valles, Río Verde and Tamasopo. }\end{array}$ & $\begin{array}{l}\text { Alaquines, Aquismón, Cárdenas, Ciudad del Maíz, Ciudad Valles, El naranjo, } \\
\text { Lagunilla, Rayón, Río Verde, Tamasopo, Tamazunchale, Tancanhuitz, Tanlajás, } \\
\text { Tierra Nueva, in the State of SLP, and Arroyo Seco y Jalpan in state of QRO. }\end{array}$ \\
\hline
\end{tabular}

SLP, San Luis Potosi; QRO, Queretaro. 


\section{Discussion}

This is the first geostatistical study on the distribution of rabies in cattle with a focus on the role of D. rotundus and the climatic variables that favour the presence of this bat species as vector of this disease in the central region of Mexico. Our results show correlation between the risk for the presence of cases and the range of maximum and minimum temperatures and rain fall. Our results agree with those reported by Patten (2004), who mentions that the vampire bat does not tolerate temperatures higher than $39{ }^{\circ} \mathrm{C}$ or lower than $10^{\circ} \mathrm{C}$, oscillating on average between $20^{\circ} \mathrm{C}$ and $27^{\circ} \mathrm{C}$. That is why it is distributed mainly in tropical and subtropical environments where there is also a high density of cattle per $\mathrm{km}^{2}$ (Lee et al., 2012; Zarza et al., 2017).

According to Patten (2004), AP, temperature and topography are better predictors for species richness in Chiroptera than vegetative cover and latitude. It has been reported that the common vampire bat can inhabit areas with a temperature difference of less than $4{ }^{\circ} \mathrm{C}$ between the cold and the warm months, i.e. a very low variation in annual temperature (McNab et al., 1973; Zarza et al., 2017). In contrast, our study found a more than three times higher average $\left(12.9^{\circ} \mathrm{C}\right)$ suggesting good adaptation of the vampire bat to the climatic conditions in the study region. It is known that $D$. rotundus does not hibernate, but lives long periods in caves, in tree holes, under bridges and in old buildings during the day where the microclimate differs from that of the general environment (Torquetti et al., 2017). In fact, it has been reported that the factors that most contribute to the spatial distribution of rabies in livestock are temperature and precipitation as these variables offer a micro- climate inside bat refuges that favour the distribution of possible infected vampire bats with the rabies virus (Bárcenas-Reyes, 2013; Bárcenas-Reyes et al., 2015; de Thoisy et al., 2016; Hayes and Piaggio, 2018). It was found that the highest risk, and the highest number of cases, occur in La Huasteca Potosina in the State of San Luis Potosí, and in La Sierra Gorda in the State of Querétaro. The reason could be that these areas offer climatic conditions appropriate for the survival of $D$. rotundus, including high livestock density. This is consistent with Hayes and Piaggio (2018), who report that the presence of vampire bats is common in various habitats of central Mexico, and that vampire bats look for areas with moderate winter temperatures that allow continuous activity throughout the year and the availability of food. The areas with medium and low risk have low livestock density, a risk factor that influences the distribution of the disease in cattle but is less important than the potential areas with climatic conditions that influence the distribution of D. rotundus (Galicia-Castillo, 2015).

One of the main risk factors for the persistence and distribution of rabies in a specific region is the presence of livestock, the main source of food for the vector $D$. rotundus. It has been previously reported that areas with a high probability of suitable conditions for this bat species in Mexico are the states of San Luis Potosi and Veracruz (Zarza et al., 2017), which are also two of the Mexican states with the highest density of cattle because of the availability of pasture. Therefore, the presence of cases of rabies correlates with the population density of cattle (Suzán, 2005; Bárcenas-Reyes et al., 2015), and it must be admitted that it would have been useful if this variable would have been included in our study.

Escobar (2016) mentions the need to evaluate prediction models using different algorithms to select the best prediction that can

Table 4. Spatial characteristics and areas with presence of cases of rabies in central Mexico over the period 2008-2013.

\begin{tabular}{|c|c|c|}
\hline Year & Pattern & Places with cases of rabies \\
\hline 22008 & Cases are reported in GTO State. & $\begin{array}{l}\text { Ahualulco, Alquines, Aquismón, Axtla, Cárdenas, Ciudad del Maíz, Ciudad Valles, } \\
\text { El naranjo, Guadalcazar, Rayón, Río Verde, San Ciro de Acosta, San Martín, } \\
\text { Tamazunchale, Tampamolón y Tanlajás in the State of SLP; Arroyo Seco, Cadereyta, } \\
\text { Jalpan, Peña Miller, and Pinal de Amoles in the State of QRO. }\end{array}$ \\
\hline 2009 & $\begin{array}{l}\text { The number of cases reported increases } \\
\text { in the three states. Average temperature of } 22.9^{\circ} \mathrm{C} \text {, } \\
\text { and average precipitation of } 1,217 \mathrm{~mm} \text {. }\end{array}$ & $\begin{array}{l}\text { Alaquines, Aquismón, Ciudad del Maíz, Ciudad Valles, Ciudad Fernandez, El naranjo, } \\
\text { Huehuetla, Rayón, Río Verde, San Ciro de Acosta, San Martín, San Vicente, Tamasopo, } \\
\text { Tampamolón, Tamuín, Tancanhuitzy Tanquean in the State of SLP; Cadereyta, Jalpan and } \\
\text { Landa de Matamoros in the State of QRO; Xichu and Atarjea in GTO. }\end{array}$ \\
\hline 2010 & $\begin{array}{l}\text { Similar number of cases in } 2010 \text { and } 2011 . \\
\text { No new places affected. }\end{array}$ & $\begin{array}{l}\text { Aquismón, Ciudad del Maíz, Ciudad Valles, Ciudad Fernández, El Naranjo, Guadalcazar, } \\
\text { Río Verde, San Luis, San Vicente, Santa Maria, Tamasopo, Tamuín, Tancanhuitz, Tierra } \\
\text { Nueva, Victoria, and Villa Juárez in the State of SLP; Ezequiel Montes y Pinal de Amoles } \\
\text { in the State of QRO; Atarjea, Sta. Catarina and Xichu in GTO. }\end{array}$ \\
\hline 2011 & $\begin{array}{l}\text { Similar number of cases in } 2010 \text { and } 2011 \text { but new } \\
\text { cases and new affected places reported. }\end{array}$ & $\begin{array}{l}\text { Aquismón, Ciudad Valles, Cerritos, Ciudad Fernández, Guadalcazar, Huehuetla, Río } \\
\text { Verde, San Antonio, San Juan, San Luis, San Martín, Santa Maria, Tamasopo, Tamuín, } \\
\text { Xilitla, and Villa Hidalgo in SLP. Cadereyta, Landa de Matamoros, Peñamiller, } \\
\text { Pinal de Amoles, and Toliman in QRO; Sta. Catarina in GTO. }\end{array}$ \\
\hline 2012 & The number of cases reported decrease by $50 \%$. & $\begin{array}{l}\text { Alaquines, Aquismón, Armadillo, Cárdenas, Ciudad Fernadez, Ciudad Valles Cocaxtlan, } \\
\text { El naranjo, Guadalcazar, Rayón, Río Verde, San Ciro, San Juan, San Luis, San Nicolas, } \\
\text { Tamasopo, Tamazunchale, and Tamuín in SLP; Arroyo Seco, Cadereyta, Ezequiel Montes, } \\
\text { Jalpan and Toliman in QRO; Sta. Catarina in GTO. }\end{array}$ \\
\hline 2013 & $\begin{array}{l}\text { The number of cases and the size of infected } \\
\text { areas decrease. }\end{array}$ & $\begin{array}{l}\text { Alaquines, Aquismón, Armadillo, Axtla, Cárdenas, Ciudad Valles, El naranjo, San Luis, } \\
\text { San Martín, San Vicente, Tamasopo, Tampacán y Tamuín, Tancanhuitz, Tanquian and } \\
\text { Zaragoza in SLP; Cadereyta, El Marques, Jalpan, and Landa de Matamoros in QRO; } \\
\text { San Jose in GTO. }\end{array}$ \\
\hline
\end{tabular}

GTO, Guanajuato; QRO, Queretaro; SLP, San Luis Potosi. 
differentiate between those of biological and those of statistical importance. The advantage of co-Kriging is that it offers results with less statistical bias because it uses secondary information correlated with the attribute under study. Multivariate co-Kriging in our study allows the study of the association between the presence of cases in cattle with different variables that include the distribution of the vector by providing unbiased global estimates in the structure of spatial variability; i.e. the variogram.

The report of cases in areas previously free of the disease in the states under study has been constant lately (Galicia-Castillo, 2015). It is not clear, however, if those cases occur because of vampire bat's bites cattle in the location where the case is reported, or the cases occur in animals brought in from endemic areas; in our data set the precise origin of the infected animals was not always available. There are reports of the presence of $D$. rotundus in these areas but only a few with infection have been found.

\section{Conclusions}

The presence of the risk for rabies in cattle has been estimated with advanced multivariate geostatistical methods based on three environmental variables: minimum and maximum temperature together with average precipitation. The outcome shows that the risk for cases in the central region of Mexico is higher in $\mathrm{La}$ Huasteca Potosina in the State of San Luis Potosí, and in La Sierra Gorda in the State of Querétaro. It seems that these endemic regions are acting as the source of infection for other regions in the area.

\section{References}

Aguirre AA, Ostfeld RS, Tabor GM, House C, Pearl MC, 2012. Conservation medicine. New directions in conservation medicine: applied cases of ecological health. Oxford University Press, New York, USA.

Bárcenas-Reyes I, 2013. Factores ambientales asociados a la transmisión vampiro-bovino de la rabia paralitica en la sierra gorda de Querétaro. Master thesis diss. Autonomous University of Querétaro, Querétaro, Mexico.

Bárcenas-Reyes I, Loza-Rubio E, Zendejas-Martínez H, LunaSoria H, Cantó-Alarcón GJ, Milian-Suazo F, 2015. Epidemiological trends in bovine paralytic rabies in central Mexico, 2001-2013. Rev Panam Salud Pública 38:396-403.

Barrios-Gómez KM, Lopez-Wilchis R, Díaz-Larrea J, GuevaraChumacero LM, 2019. Spatial distribution of bats richness in Mexico at different taxonomic levels: biogeographical and conservation implications. Therya 10:11.

Bonwitt J, Oltean H, Lang M, Kelly RM, Goldoft M, 2018. Bat rabies in Washington State: temporal-spatial trends and risk factors for zoonotic transmission (2000-2017). PloS One 13:e0205069.

Cárdenas-Contreras ZL, 2017. Análisis espacio temporal de la rabia bovina de origen silvestre en Colombia (2005-2014). Master thesis diss. Faculty of Veterinary Medicine, Autonomous University of Barcelona, Barcelona, Spain.

Caro-Benito, A. 2012. Modelización geoestadística para la predicción de actividad de Cs en suelo. PhD thesis diss. Autonomous University of Madrid, Spain. Avaialble from: http://hdl.han- dle.net/10486/12304

Clements AC, Pfeiffer DU, 2009. Emerging viral zoonoses: frameworks for spatial and spatiotemporal risk assessment and resource planning. Vet J 182:21-30.

de Andrade FA, Gomes MN, Uieda W, Begot AL, Ramos ODS, Fernandes ME, 2016. Geographical analysis for detecting high-risk areas for bovine/human rabies transmitted by the common hematophagous bat in the amazon region, Brazil. PloS One 11:e0157332.

de Thoisy B, Bourhy H, Delaval M, Pontier D, Dacheux L, Darcissac E, Salmier A, 2016. Bioecological drivers of rabies virus circulation in a neotropical bat community. PLoS Negl Trop Dis 10:e0004378.

Escobar LE, 2016. Modelos de nicho ecológico en salud pública: cinco preguntas cruciales. Rev Panam Salud Pública 40:98.

Galicia-Castillo JJ, 2015. Distribución geográfica del riesgo de rabia humana transmitida por el murciélago vampiro (Desmodus rotundus) en el estado de San Luis Potosí. Repositorio Nacional Conacyt. Available from: https://ninive.uaslp.mx/xmlui/handle/i/3847

Gomes MN, Monteiro AMV, Lewis N, Gonçalves CA, de Souza Nogueira Filho V, 2010. Landscape risk factors for attacks of vampire bats on cattle in Sao Paulo, Brazil. Prev Vet Med 93:139-46.

Guo D, Zhou H, Zou Y, Yin W, Yu H, Si Y, Magalhães RS, 2013. Geographical analysis of the distribution and spread of human rabies in china from 2005 to 2011. PloS One 8:e72352.

Hampson K, Coudeville L, Lembo T, Sambo M, Kieffer A, Attlan M, Barrat J, Blanton JD, Briggs DJ, Cleaveland S, Costa P, Freuling CM, Hiby E, Knopf L, Inclinaciones F, Meslin FX, Metlin A, Miranda ME, Müller T, Nel LH, Recuenco S, Rupprecht CE, Schumacher C, Taylor L, Vigilato MA, Zinsstag J, Dushoff J, 2015. Estimating the global burden of endemic canine rabies. PLoS Negl Trop Dis 9:e0003709.

Hayes MA, Piaggio AJ, 2018. Assessing the potential impacts of a changing climate on the distribution of a rabies virus vector. PloS One 13:e0192887.

IMTA, 2006. Banco de datos histórico nacional del Servicio Meteorológico Nacional. Base de datos digital. Instituto Mexicano de Tecnología del Agua, Mexico City, Mexico.

Johnson N, Aréchiga-Ceballos N, Aguilar-Setien A, 2014. Vampire bat rabies: ecology, epidemiology and control. Viruses 6:191128.

Lee DN, Papeş M, Van Den Bussche RA, 2012. Present and potential future distribution of common vampire bats in the Americas and the associated risk to cattle. PLoS One 7:e42466.

Loza-Rubio E, Nadin-Davis SA, Morales Salinas E, 2012. Caracterización molecular y biológica del virus de la Rabia que circula en zorrillos de México enfocado a la variante del gen de la fosfoproteína (P). Rev Mex Cienc Pecu 3:155-70.

McNab BK, 1973. Energetics and the distribution of vampires. J Mammal 54:131-44.

Mengistu TS, Haile AW, 2017. Review on the application of geographical information systems (GIS) in veterinary medicine. Int J Vet Health Sci Res 5:176-82.

PAHO, 2013. Procedimiento para la declaración de países o territorios libres de rabia canina. Pan American Health Organization, Pan American Foot-and-Mouth Disease Center, Veterinary Public Health Unit, Rio de Janeiro, Brazil.

Patten MA, 2004. Correlates of species richness in North 
American bat families. J Biogeogr 31:975-85.

Rodenbusch CR, Ferreira JC, da Rosa JCA, Migliavacca VF, Bertagnolli AC, Peres ME, de Almeida LL, 2016. Spatial and temporal description of laboratory diagnosis of bovine rabies in the state of Rio Grande do Sul, Brazil. Acta Sci Vet 44:1-8.

Suzán G, 2005. Desmodus rotundus. In: Ceballos G, Oliva G, eds. Los mamíferos silvestres de México. Comisión Nacional para el Conocimiento y Uso de la Biodiversidad, Fondo de Cultura Económica, México.

Torquetti CG, Silva MX, Talamoni SA, 2017. Differences between caves with and without bats in a Brazilian karst habitat. Zoologia (Curitiba) 34:e13732.

Vigilato MAN, Clavijo A, Knobl T, Silva HMT, Cosivi O,
Schneider MC, Espinal MA, 2013. Progress towards eliminating canine rabies: policies and perspectives from Latin America and the Caribbean. Philos Trans R Soc Lond B Biol Sci 368:20120143.

Wackernagel H, 1998. Multivariate geostatistics, an introduction with applications. Springer, Berlin, Germany.

WHO, 2013. WHO expert consultation on rabies: second report (No. 982). World Health Organization, Geneva, Switzerland.

Zarza H, Martínez-Meyer E, Suzán G, Ceballos G, 2017. Geographic distribution of Desmodus rotundus in Mexico under current and future climate change scenarios: Implications for BPR infection. Vet Méx 4:1-16. 